\title{
Ruegeria pelagia is a later heterotypic synonym of Ruegeria mobilis
}

\author{
Correspondence \\ Zongze Shao \\ shaozz@163.com \\ Tianling Zheng \\ wshwzh@xmu.edu.cn
}

\author{
Qiliang Lai, ${ }^{1,2}$ † Jun Yuan, ${ }^{3}$ † Fuying Li, ${ }^{2}$ Tianling Zheng ${ }^{1}$ and Zongze Shao ${ }^{2}$ \\ ${ }^{1} \mathrm{MOE}$ of Key Lab for Coast and Wetland Ecosystem, School of Life Sciences, Xiamen University, \\ Xiamen 361005, PR China \\ ${ }^{2}$ Key Laboratory of Marine Biogenetic Resources, Third Institute of Oceanography, State Oceanic \\ Administration, Xiamen, PR China \\ ${ }^{3}$ College of Life Science, Fujian Agriculture and Forestry University, Fuzhou, PR China
}

Ruegeria mobilis Muramatsu et al. 2007 and Ruegeria pelagia Lee et al. 2007 were reported separately as novel species in June and August 2007. They were originally isolated from marine environments of Japan and Palau and from the Sargasso Sea, respectively. Although the two type strains differ by only one base in their almost full-length $16 \mathrm{~S}$ rRNA gene sequences, a comparative study of $R$. pelagia and $R$. mobilis has not been reported at the time of writing. The present study aims to determine the exact taxonomic positions of $R$. pelagia NBRC $102038^{\mathrm{T}}$ and $R$. mobilis NBRC $101030^{\mathrm{T}}$ by using a polyphasic taxonomic approach.

R. pelagia NBRC $102038^{\mathrm{T}}$ and R. mobilis NBRC $101030^{\mathrm{T}}$ were obtained from the NITE Biological Resource Center (NBRC), Chiba, Japan. Genomic DNA was prepared according to the method of Ausubel et al. (1995) and the $16 \mathrm{~S}$ rRNA gene was amplified by PCR using previously described primers (Liu \& Shao, 2005). Sequences of related taxa were obtained from the GenBank database (http://www.ncbi.nlm.nih.gov/). Phylogenetic analysis was

†These authors contributed equally to this work.

Abbreviation: rep-PCR, repetitive element-based PCR.

The GenBank/EMBL/DDBJ accession numbers for the sequences reported in this study are EU977138 (R. pelagia NBRC $102038^{\top} 16 \mathrm{~S}$ rRNA gene), EU977136 (R. pelagia NBRC $102038^{\top}$ partial gyrB gene), EU977137 (R. mobilis NBRC 101030 ${ }^{\top}$ 16S rRNA gene) and EU977135 (R. mobilis NBRC $101030^{\top}$ partial gyrB gene).

A transmission electron micrograph of cells of $R$. pelagia NBRC $102038^{\top}$, a dendrogram based on gyrB sequences and a comparison of rep-PCR patterns are available as supplementary material with the online version of this paper. performed using MEGA version 4 (Tamura et al., 2007) after multiple sequence alignment by using DNAMAN (version 5.1; Lynnon Biosoft). Distances (distance options according to Kimura's two-parameter model) and clustering with the neighbour-joining method of Saitou \& Nei (1987) and minimum-evolution method of Rzhetsky \& Nei (1992, 1993) were determined by using bootstrap values based on 1000 replications.

Resequencing of the 16S rRNA genes showed that the two strains differ in only one nucleotide position, as indicated by the previously reported sequences. The phylogenetic tree obtained in this study (not shown) was similar to that of Vandecandelaere et al. (2008). In the tree, the two strains formed a clade within the genus Ruegeria. DNA-DNA hybridization between genomic DNA from $R$. pelagia NBRC $102038^{\mathrm{T}}$ and R. mobilis NBRC $101030^{\mathrm{T}}$ was performed as described previously (Liu \& Shao, 2005) with duplicate reciprocal hybridizations. Genomic DNA from Escherichia coli DH5 $\alpha$ was used as an outgroup sample. Salmon-sperm DNA was used as a negative control. DNA-DNA hybridization between $R$. pelagia NBRC $102038^{\mathrm{T}}$ and $R$. mobilis NBRC $101030^{\mathrm{T}}$ was $91 \pm 4 \%$, suggesting that the two strains belong to a single species (Wayne et al., 1987).

To elucidate further the taxonomic relationship between $R$. pelagia NBRC $102038^{\mathrm{T}}$ and R. mobilis NBRC $101030^{\mathrm{T}}$, biochemical tests were carried out with API 20NE and API ZYM strips (bioMérieux) according to the manufacturer's instructions, except that the $\mathrm{NaCl}$ concentration in all tests was adjusted to $3.0 \%$. Antibiotic susceptibility tests were performed by the disc diffusion method (Shieh et al., 
2003). All antibiotic sensitivity tests were performed with Oxoid discs. $R$. pelagia NBRC $102038^{\mathrm{T}}$ and $R$. mobilis NBRC $101030^{T}$ had almost identical reactions in these tests (Table 1). Lee et al. (2007) reported that $R$. pelagia NBRC

Table 1. Characteristics of R. pelagia NBRC $102038^{\top}$ and $R$. mobilis NBRC $101030^{\top}$

In this study, both strains were positive for catalase and oxidase, sensitive to ( $\mu \mathrm{g}$ per disc unless indicated) ampicillin (10), carbenicillin (100), cefobid (30), chloromycetin (30), ciprofloxacin (5), erythromycin (15), gentamicin (10), minomycin (30), norfloxacin (10), ofloxacin (5), piperacillin (100), polymyxin B (30 U), rifampicin (5), rocephin (30), tetracycline (30) and vibramycin (30) and resistant to cefalexin (30), cefazolin (30), cephradin (30), clindamycin (2), cotrimoxazole (25), lincomycin (2), metronidazole (5), oxacillin (1) and penicillin G (10). In API 20NE tests, both strains were positive for Dglucose fermentation, $\beta$-glucosidase activity and utilization of $\mathrm{D}$ glucose, maltose, D-mannitol, D-mannose, L-arabinose, malic acid, $\mathrm{N}$ acetylglucosamine and phenylacetic acid and negative for nitrate reduction, indole production, activities of arginine dihydrolase and urease, gelatin hydrolysis and utilization of adipic acid, capric acid, potassium gluconate and trisodium citrate. In API ZYM tests, both strains were positive for acid phosphatase, alkaline phosphatase, esterase (C4), esterase lipase (C8), leucine aminopeptidase, lipase (C14), $N$-acetyl- $\beta$-glucosaminidase, naphthol-AS-BI-phosphohydrolase, valine aminopeptidase and $\alpha$-glucosidase, weakly positive for cystine aminopeptidase and negative for trypsin, $\alpha$-chymotrypsin, $\alpha$ fucosidase, $\alpha$-galactosidase, $\alpha$-mannosidase, $\beta$-galactosidase, $\beta$-glucosidase and $\beta$-glucuronidase. + , Positive; $\mathrm{w}$, weakly positive; negative. Data were obtained in this study unless indicated.

\begin{tabular}{|lcc|}
\hline Characteristic & R. mobilis & R. pelagia \\
NBRC & NBRC \\
& $\mathbf{1 0 1 0 3 0}^{\mathbf{T}}$ & $\mathbf{1 0 2 0 3 8}^{\mathbf{T}}$ \\
\hline Cell size $(\mu \mathrm{m})$ & & \\
Length & $1.0-2.0^{a}$ & $0.8-2.1^{b}$ \\
Width & $0.6-0.8^{a}$ & $0.7-1.2^{b}$ \\
pH for growth & & \\
Range & $5-11^{a}$ & $4-12^{b}$ \\
Optimum & $7^{a}$ & $5-6^{b}$ \\
Temperature for growth $\left({ }^{\circ} \mathrm{C}\right)$ & & \\
Range & $5-35^{a}$ & $16-42^{b}$ \\
Optimum & $20-25^{a}$ & $30-37^{b}$ \\
NaCl concentration for growth (\% w/v) & & \\
Range & $0-10^{a}$ & $0-10^{b}$ \\
Optimum & $1-3^{a}$ & $3.5^{b}$ \\
Antibiotic susceptibility & & \\
Neomycin $(10 \mu \mathrm{g})$ & $\mathrm{W}$ & - \\
Vancomycin $(30 \mu \mathrm{g})$ & $\mathrm{W}$ & - \\
Furazolidone $(15 \mu \mathrm{g})$ & + & - \\
Kanamycin $(30 \mu \mathrm{g})$ & + & $\mathrm{W}$ \\
Streptomycin $(10 \mu \mathrm{g})$ & + & $\mathrm{W}$ \\
DNA G+C content $(\mathrm{mol} \%)$ & + & $\mathrm{W}$ \\
$\beta$-Galactosidase $(\mathrm{API} 20 \mathrm{NE})$ & $58.5^{a}$ & $58.4^{b}$ \\
& + & \\
\hline
\end{tabular}

${ }^{\star}$ Data from: a, Muramatsu et al. (2007); b, Lee et al. (2007).
$102038^{\mathrm{T}}$ was not motile, in contrast to $R$. mobilis NBRC $101030^{\mathrm{T}}$ (Muramatsu et al., 2007). In this report, however, we found that $R$. pelagia NBRC $102038^{\mathrm{T}}$ had a polar flagellum (Supplementary Fig. S1, available in IJSEM Online). Electron microscopy was performed according to the method of Lai et al. (2009). Motility was tested by penetrating the strains into soft agar according to Dong \& Cai (2001), and the result showed that both $R$. pelagia NBRC $102038^{\mathrm{T}}$ and R. mobilis NBRC $101030^{\mathrm{T}}$ were motile.

Further comparison of R. pelagia NBRC $102038^{\mathrm{T}}$ with $R$. mobilis NBRC $101030^{\mathrm{T}}$ was based on sequencing of the housekeeping gene gyrB and repetitive element-based PCR (rep-PCR) fingerprinting. The gyrB genes of the two type strains were sequenced (about 1072 bp) (Yamamoto et al., 2000 ), and the similarity between strain $R$. pelagia NBRC $102038^{\mathrm{T}}$ and R. mobilis NBRC $101030^{\mathrm{T}}$ was $97.7 \%$; the deduced GyrB amino acid sequence identity between the two strains was $99.2 \%$. As shown in Supplementary Fig. S2, a phylogenetic tree based on gyrB gene sequences demonstrated that $R$. pelagia NBRC $102038^{\mathrm{T}}$ and $R$. mobilis NBRC $101030^{\mathrm{T}}$ formed a separate branch within the genus Ruegeria, as observed with $16 \mathrm{~S}$ rRNA gene sequence analysis. In addition, the primer BOX-A1R ( $5^{\prime}$-CTACGGCAAGGCGACGCTGACG-3') was used for rep-PCR fingerprint analysis (Versalovic et al., 1991). The PCR was carried out according to Versalovic et al. (1991) and the PCR products were separated by agarose (2\%) gel electrophoresis. $R$. pelagia NBRC $102038^{\mathrm{T}}$ and R. mobilis NBRC $101030^{\mathrm{T}}$ had similar rep-PCR fingerprints (Supplementary Fig. S3). This supports the high relatedness at the DNA level found by DNA-DNA hybridization.

On the basis of data described above, we conclude that the strains described as Ruegeria pelagia match the genomic characteristics of Ruegeria mobilis, and that Ruegeria pelagia Lee et al. 2007 must therefore be seen as a later heterotypic synonym of Ruegeria mobilis Muramatsu et al. 2007.

\section{Acknowledgements}

This work was supported financially by the Natural Science Foundation of Fujian Province of China (no. 2009J01177) and the National Infrastructure of Natural Resources for Science and Technology Program of China (no. 2005DKA21209).

\section{References}

Ausubel, F. M., Brent, R., Kingston, R. E., Moore, D. D., Seidman, J. G., Smith, J. A. \& Struhl, K. (editors) (1995). Short Protocols in Molecular Biology: a Compendium of Methods from Current Protocols in Molecular Biology, 3rd edn. New York: Wiley.

Dong, X.-Z. \& Cai, M.-Y. (2001). Determinative Manual for Routine Bacteriology. Beijing: Scientific Press (English translation).

Lai, Q., Yuan, J., Wu, C. \& Shao, Z. (2009). Oceanibaculum indicum gen. nov., sp. nov., isolated from deep seawater of the Indian Ocean. Int J Syst Evol Microbiol 59, 1733-1737. 
Lee, K., Choo, Y.-J., Giovannoni, J. S. \& Cho, J.-C. (2007). Ruegeria pelagia sp. nov., isolated from the Sargasso Sea, Atlantic Ocean. Int $J$ Syst Evol Microbiol 57, 1815-1818.

Liu, C. \& Shao, Z. (2005). Alcanivorax dieselolei sp. nov., a novel alkane-degrading bacterium isolated from sea water and deep-sea sediment. Int J Syst Evol Microbiol 55, 1181-1186.

Muramatsu, Y., Uchino, Y., Kasai, H., Suzuki, K. \& Nakagawa, Y. (2007). Ruegeria mobilis sp. nov., a member of the Alphaproteobacteria isolated in Japan and Palau. Int J Syst Evol Microbiol 57, 1304-1309.

Rzhetsky, A. \& Nei, M. (1992). A simple method for estimating and testing minimum evolution trees. Mol Biol Evol 9, 945-967.

Rzhetsky, A. \& Nei, M. (1993). Theoretical foundation of the minimum-evolution method of phylogenetic inference. Mol Biol Evol 10, 1073-1095.

Saitou, N. \& Nei, M. (1987). The neighbor-joining method: a new method for reconstructing phylogenetic trees. Mol Biol Evol 4, 406-425.

Shieh, W. Y., Chen, Y.-W., Chaw, S.-M. \& Chiu, H.-H. (2003). Vibrio ruber sp. nov., a red, facultatively anaerobic, marine bacterium isolated from sea water. Int J Syst Evol Microbiol 53, 479-484.
Tamura, K., Dudley, J., Nei, M. \& Kumar, S. (2007). MEGA4: molecular evolutionary genetics analysis (MEGA) software version 4.0. Mol Biol Evol 24, 1596-1599.

Vandecandelaere, I., Nercessian, O., Segaert, E., Achouak, W., Faimali, M. \& Vandamme, P. (2008). Ruegeria scottomollicae sp. nov., isolated from a marine electroactive biofilm. Int J Syst Evol Microbiol 58, 2726-2733.

Versalovic, J., Koeuth, T. \& Lupski, J. R. (1991). Distribution of repetitive DNA sequences in eubacteria and application to fingerprinting of bacterial genomes. Nucleic Acids Res 19, 68236831.

Wayne, L. G., Brenner, D. J., Colwell, R. R., Grimont, P. A. D., Kandler, O., Krichevsky, M. I., Moore, L. H., Moore, W. E. C., Murray, R. G. E. \& other authors (1987). International Committee on Systematic Bacteriology. Report of the ad hoc committee on reconciliation of approaches to bacterial systematics. Int J Syst Bacteriol 37, 463-464.

Yamamoto, S., Kasai, H. L., Arnold, D. W., Jackson, R., Vivian, A. \& Harayama, S. (2000). Phylogeny of the genus Pseudomonas: intrageneric structure reconstructed from the nucleotide sequences of gyrB and rpoD genes. Microbiology 146, 2385-2394. 